\title{
Pengaruh pertumbuhan ekonomi, tingkat kemiskinan, pengeluaran pemerintah, tingkat pengangguran terbuka terhadap Indeks Pembangunan Manusia (IPM) Provinsi-provinsi di Sumatera
}

\author{
*Dzaki Furqoni ZA; Junaidi; Adi Bhakti
}

Prodi Ekonomi Pembangunan, Fakultas Ekonomi dan Bisnis, Universitas Jambi

*E-mail korespondensi: dzakifurqoni87@gmail.com

\begin{abstract}
Study are as follows: To analyze the effect of economic growth, poverty level, government expenditure and open unemployment on the Human Development Index (HDI) of the Provincial Provinces in Sumatra for the period 2013-2017. Based on the results of the study that economic growth has a significant effect on the human development index. Poverty level has a significant effect on the human development index. Open unemployment has a significant effect on the human development index. Government expenditure has a significant effect on the Human Development Index.

Keywords: Economic Growth, Poverty Level, Government Expenditures, Open Unemployment Rate, and Human Development Index.
\end{abstract}

\begin{abstract}
Abstrak
Tujuan penelitian ini adalah sebagai berikut: Untuk menganalisis pengaruh pertumbuhan ekonomi, tingkat kemiskinan, pengeluaran pemerintan dan tingkat pengangguran terbuka terhadap Indeks Pembangunan Manusia (IPM) Provinsi Provinsi di Sumatera periode 2013-2017. Berdasarkan hasil penelitian bahwa pertumbuhan ekonomi berpengaruh signifikan terhadap indeks pembangunan manusia. Tingkat kemiskinan berpengaruh signifikan terhadap indeks pembangunan manusia. Tingkat pengangguran terbuka berpengaruh signifikan terhadap indeks pembangunan manusia. Pengeluaran pemerintah berpengaruh signifikan terhadap indeks pembangunan manusia. Kata Kunci: Pertumbuhan Ekonomi, Tingkat Kemiskinan, Pengeluaran Pemerintah, Tingkat Pengangguran Terbuka, dan Indeks Pembangunan Manusia.
\end{abstract}

\section{PENDAHULUAN}

Pembangunan merupakan suatu proses berkesinambungan yang direncanakan untuk memperbaiki berbagai aspek kehidupan masyarakat. Tujuan akhir pembangunan adalah kesejahteraan masyarakat. Manusia bukan hanya merupakan objek pembangunan tetapi diharapkan dapat menjadi subjek sehingga dapat memberikan kontribusi yang bermanfaat bagi kemajuan suatu wilayah atau daerah yang secara makro menjadi kemajuan suatu negara.

Untuk melihat sejauh mana keberhasilan pembangunan dan kesejahteraan manusia, United Nation Development Programme (UNDP) telah menerbitkan suatu indikator yaitu Indeks Pembangunan Manusia (IPM) untuk mengukur keberhasilan pembangunan dan kesejahteraan suatu negara.

Pembangunan manusia merupakan paradigma pembangunan yang menempatkan manusia sebagai fokus dan sasaran akhir dari seluruh kegiatan pembangunan, yaitu tercapainya penguasaan atas sumber daya (pendapatan untuk mencapai hidup layak), 
peningkatan derajat kesehatan (usia hidup panjang dan sehat) dan meningkatkan pendidikan.

Berdasarkan data Badan Pusat Statistik memperlihatkan bahwa IPM di Sumatera Tahun 2013-2017 mengalami peningkatan yang cukup berarti dalam beberapa tahun terakhir. IPM yang paling tertinggi terjadi pada Provinsi Kep. Riau yaitu sebesar 73,02 pada tahun 2013, 73,40 pada tahun 2014, 73,35 persen pada tahun 2015 dan pada tahun 2016 meningkat menjadi sebesar 73,99 persen. Pada tahun 2017 IPM kembali meningkat menjadi sebesar 74,45 Sedangkan IPM yang terendah terjadi pada Provinsi Lampung yaitu sebesar 65,73 persen pada tahun 2013, pada tahun 2014 sebesar 66,42 persen, sebesar 66,95 persen pada tahun 2015 dan pada tahun 2016 meningkat sebesar 67,75 persen. Pada tahun 2017 IPM meningkat kembali menjadi sebesar 68,25 Rata-rata IPM di Provinsi Sumatera Tahun 2013-2017 sebesar 69,72 persen.

Sayangnya, peningkatan laju Indeks Pembangunan Manusia (IPM) tidak sama dengan peningkatan pertumbuhan ekonomi dan tingkat kemiskinan. Pertumbuhan ekonomi di Sumatera selama tahun 2013-2017 mengalami fluktuasi. Berdasarkan Badan Pusat Statistik pertumbuhan ekonomi di Pulau Sumatera Mengalami fluktuasi. Pertumbuhan ekonomi yang paling tertinggi pada tahun 2013 sebesar 7,21 persen. Pada tahun 2014 mengalami penurunan menjadi sebesar 6,60 persen. Pada tahun 2015 adalah Provinsi Kep Riau sebesar 6,02 persen dan pada tahun 2016 juga pada Kep. Riau sebesar 5,02 persen. Pada tahun 2017 pertumbuhan ekonomi menurun menjadi sebesar 2,01. Sedangkan pertumbuhan ekonomi yang paling terendah adalah Provinsi Riau pada tahun 2013 sebesar 2,48 persen. Pada tahun 2014 mengalami peningkatn menjadi sebesar 2,71 persen. Pada tahun 2015 menurun menjadi sebesar 0,22 persen dan pada tahun 2016 sebesar 2,23 persen. Pada tahun 2017 meningkat dari tahun sebelumnya menjadi sebesar 2,71 persen. Rata-rata pertumbuhan ekonomi di Provinsi Sumatera pada tahun 2013-2017 adalah sebesar 4,72 persen.

Napitupulu (2007), mengatakan bahwa Indeks Pembangunan Manusia mempunyai pengaruh dalam penurunan jumlah penduduk miskin. Indeks Pembangunan Manusia memiliki indikator komposit dalam penghitungannya antara lain angka harapan hidup, angka melek huruf, dan konsumsi per kapita. Peningkatan pada sektor kesehatan dan pendidikan serta pendapatan per kapita memberikan kontribusi bagi pembangunan manusia, sehingga semakin tinggi kualitas manusia pada suatu daerah akan mengurangi jumlah penduduk miskin di daerah.

Berdasarkan Badan Pusat Statistik terlihat di Sumatera ada yang mengalami peningkatan tingkat kemiskinannya ada juga yang mengalami penurunan. Tingkat kemiskinan yang paling tertinggi terjadi di Provinsi Sumatera Utara pada tahun 2013 tingkat kemiskinan sebesar 10,39 persen. Pada tahun 2014 mengalami penurunan menjadi sebesar 9,85 persen. Pada tahun 2015 mengalami peningkatan menjadi sebesar 10,79 persen dan pada tahun 2016 mengalami penurunan menjadi sebesar 10,27 persen. Pada tahun 2017 tingkat kemiskinan menurun dari tahun sebelumnya menjadi sebesar 9,28 persen. Sedangkan tingkat kemiskinan yang paling terendah terjadi di Provinsi Bangka Belitung yaitu pada tahun 2013 sebesar 5,25 persen. Pada tahun 2014 menurun menjadi sebesar 4,97 persen. Pada tahun 2015 turun kembali menjadi sebesar 4,83 dan pada tahun 2016 mengalami peningkatan menjadi sebesar 5,04 persen. Pada tahun 2017 tingkat kemiskinan meningkat menjadi sebesar 5,30 persen. Rata-rata tingkat kemiskinan di Provinsi Sumatera pada tahun 2013-2017 sebesar 9,54 persen

Dengan meningkatnya laju pertumbuhan ekonomi dari tahun ke tahun serta menurunnya tingkat kemiskinan, peningkatan laju pembangunan manusia sudah seharusnya juga dapat meningkat secara signifikan begitu pula dengan peningkatan laju 
pertumbuhan serta penurunan tingkat kemiskinan. Tetapi dalam kenyataannya perkembangan IPM di Provinsi Sumatera mengalami kenaikan walaupun kenaikannya tidaklah terlalu besar.

Todaro (2000) juga mengatakan bahwa pembangunan manusia merupakan tujuan pembangunan itu sendiri. Yang mana pembangunan manusia memainkan peranan kunci dalam membentuk kemampuan sebuah negara dalam menyerap teknologi modern untuk mengembangkan kapasitasnya agar tercipta kesempatan kerja untuk mengurangi jumlah pengangguran untuk melakukan pembangunan manusia yang berkelanjutan.

Berdasarkan Badan Pusat Statistik terlihat bahwa tingkat pengangguran terbuka di Sumatera selama tahun 2013-2016 mengalami fluktuasi Tingkat penganguran terbuka yang paling tertinggi terjadi di Provinsi Aceh pada tahun 2013 tingkat pengangguran terbuka sebesar 10,12 persen. Pada tahun 2014 mengalami penurunan menjadi sebesar 9,02 persen. Pada tahun 2015 mengalami peningkatan menjadi sebesar 9,93 persen dan pada tahun 2016 mengalami penurunan menjadi sebesar 7,57 persen. Pada tahun 2017 TPT menurun menjadi sebesar 6,57 persen. Sedangkan tingkat pengangguran terbuka yang paling terendah terjadi di Provinsi Bangka Belitung yaitu pada tahun 2013 sebesar 3,65 persen. Pada tahun 2014 meningkat menjadi sebesar 5,14 persen. Pada tahun 2015 meningkat kembali menjadi sebesar 6,29 dan pada tahun 2016 mengalami penurunan menjadi sebesar 2,60 persen. Pada tahun 2017 TPT meningkat dari tahun sebelumnya menjadi sebesar 3,78 persen. Rata-rata tingkat pengangguran terbuka di Provinsi Sumatera pada tahun 2013-2017 sebesar 5,82 persen

Pengeluaran pemerintah untuk pembangunan manusia yang diwujudkan melalui peningkatan daya beli akan mendorong kenaikan permintaan produk kebutuhan rumah tangga lokal secara menyeluruh. Meningkatnya permintaan barang produk lokal akan memberikan ransangan yang besar kepada produsen lokal, memperbesar kesempatan kerja, dan menumbuhkan investasi. Kemudian stuktur belanja APBD baik itu dari belanja modal, belanja pegawai, dan belanja daerah direalisasikan untuk pembangunan dan pelayanan publik, dimana dari komponen belanja daerah tersebut terdapat salah satu faktor pembentuk IPM yang tentunya akan meningkatkan pencapaian Indeks Pembangunan Manusia.

Berdasarkan Badan Pusat Statistik terlihat bahwa pengeluaran pemerintah di Sumatera selama tahun 2013-2016 mengalami peningkatan. Pengeluaran pemerintah yang paling tertinggi terjadi di Provinsi Sumatera Utara pada tahun 2013 pengeluaran pemerintah sebesar 29.769.495 juta rupiah. Pada tahun 2014 mengalami penurunan menjadi sebesar 32.746.365 juta rupiah. Pada tahun 2015 mengalami peningkatan menjadi sebesar 35.949.506 juta rupiah dan pada tahun 2016 mengalami peningkatan kembali menjadi sebesar 43.846.662 juta rupiah. Pada tahun 2017 kembali meningkat menjadi sebesar 45.516.845 juta rupiah.

Sedangkan pengeluaran pemerintah yang paling terendah terjadi di Provinsi Bengkulu yaitu pada tahun 2013 sebesar 6.226.235 juta rupiah. Pada tahun 2014 meningkat menjadi sebesar 6.897.909 juta rupiah. Pada tahun 2015 meningkat kembali menjadi sebesar 7.902.999 juta rupiah dan pada tahun 2016 mengalami peningkatn menjadi sebesar 9.702.473 juta rupiah. Pada tahun 2017 kembali meningkat menjadi sebesar 10.491.181 juta rupiah.

Berdasarkan uraian di atas, maka dalam penelitian ini akan dilihat sejauh mana pengaruh beberapa faktor seperti pertumbuhan ekonomi dan kemiskinan dapat mempengaruhi indeks pembangunan manusia. Oleh karena itu penelitian ini berjudul "Pengaruh Pertumbuhan Ekonomi, Tingkat Kemiskinan, Pengeluaran Pemerintah dan 
Tingkat Pengangguran Terbuka Terhadap Indeks Pembangunan Manusia (IPM) Provinsi Provinsi di Sumatera".

\section{METODE}

\section{Jenis dan Sumber Data}

Jenis data yang digunakan adalah data sekunder (time series) mulai dari tahun 2013-2017, meliputi: 1) Data Indeks Pembangunan Manusia Provinsi Provinsi di Sumatera; 2) Data Pertumbuhan Ekonomi Provinsi Provinsi di Sumatera; 3) Data Tingkat Kemiskinan Provinsi Provinsi di Sumatera; 4) Data Pengeluaran Pemerintah Provinsi Provinsi di Sumatera; 5) Data Tingkat Pengangguran Terbuka Provinsi Provinsi di Sumatera. Sumber data berasal dari BPS dan Bank Indonesia.

\section{Metode Analisis Data}

\section{Metode Analisis Deskriptif}

Alat analisis deskriptif dalam bentuk perkembangan dengan rumus sebagai berikut:

$$
\mathrm{G}=\frac{I P M_{1}-I P M_{0}}{I P M_{0}} \times 100 \%
$$

Dimana:

$\mathrm{G} \quad=$ Laju indeks pembangunan manusia

$\mathrm{IPM}_{1}=$ Indeks pembangunan manusia tahun sekarang

$\mathrm{IPM}_{0}=$ indeks pembangunan manusia tahun sebelumnya

\section{Metode Analisis Deskriptif Kuantitatif}

Untuk menjawab tujuan kedua metode yang digunakan dalam penulisan ini adalah metode kuantitatif dan menggabungkan observasi data deret waktu dan data cross section atau bersifat data panel. Model regresi data panel sebagai berikut:

Dimana:

$$
\mathrm{IPM}_{\mathrm{it}}=\boldsymbol{\beta 0}+\boldsymbol{\beta}_{1} \mathbf{P E}_{\mathrm{it}}+\boldsymbol{\beta}_{2} \mathrm{KM}_{\mathrm{it}}+\boldsymbol{\beta}_{3} \mathbf{P P}_{\mathrm{it}}+\boldsymbol{\beta}_{4} \mathbf{P G}_{\text {it }} \mathrm{e}
$$

IPM = Indeks pembangunan manusia Provinsi Provinsi di Sumatera

$\mathrm{PE} \quad=$ Pertumbuhan Ekonomi Provinsi Provinsi di Sumatera

$\mathrm{KM}=$ Kemiskinan Provinsi Provinsi di Provinsi Sumatera

$\mathrm{PP} \quad=$ Pengeluaran Pemerintah Provinsi Provinsi di Sumatera

PG = Pengangguran Provinsi Provinsi di Sumatera

I $\quad=$ Jumlah observasi di Sumatera $=>10$

$\mathrm{T} \quad=$ Tahun data observasi $($ Tahun/deret waktu) $=>5$ tahun

$\alpha \quad=$ Kostanta

$\beta \mathrm{i} \quad=$ Koefisien (banyaknya peubah bebas) $=>1,2,3$

e $\quad=$ Komponen error term

\section{Pemilihan Model Regresi Data Panel}

Pemilihan antara model PLS dengan FEM

Untuk mengetahui apakah model FEM lebih Baik dibandingkan Model PLS dapat dilakukan dengan melihat signifikansi model FEM dapat dilakukan dengan Uji statistic F, Pengujian Seperti ini dikenal dengan istilah Uji Chow atau Likelihood Test Ratio. Hipotesis nol (H0) yang digunakan adalah intersep dan slope adalah sama. Adapun uji F statisticnya adalah sebagai berikut:

$$
F_{\text {hitung }} \frac{\left(R S S_{1}-R S S_{2}\right) / n-1}{\left(R S S_{2}\right) /(n T-n-k)}
$$


Dengan $\mathrm{n}$ adalah jumlah individu, $\mathrm{T}$ merupakan jumlah periode waktu dan $\mathrm{K}$ adalah banyaknya parameter dalam model FEM: serta RSS1 dan RSS2 berturut turut adalah residual sum of square untuk model PLS dan model FEM.

Nilai statistic F akan mengikuti distribusi statistic F dengan derajat bebas sebesar n-1 untuk numerator dan sebesar nT-k untuk denumerator. Jika nilai statistic F lebih besar dari nilai $\mathrm{F}$ table pada tingkat signifikan tertentu, hipotesis nol akan di tolak, yang berarti asumsi koefisien intersep dan slope adalah sama tidak berlaku, sehingga tekhnik regresi data panel dengan FEM lebih baik dari model regresi data Panel dengan PLS.

\section{Pemilihan antara PLS dengan REM}

Untuk mengetahui apakah model REM lebih baik dibandingkan model PLS dapat dilakukan dengan uji Lagrange Multiplier (LM) yang dikembangkan oleh BruescPagan. Pengujian ini didasarkan pada nilai residual dari PLS. Hipotesis nol (H0) yang digunakan adalah intersep bukan merupakan peubah random atau stokastik, dengan kata lain varian dari residual pada persamaan bernilai nol.

Adapun nilai statistic LM di hitung berdasarkan formulasi sebagai berikut:

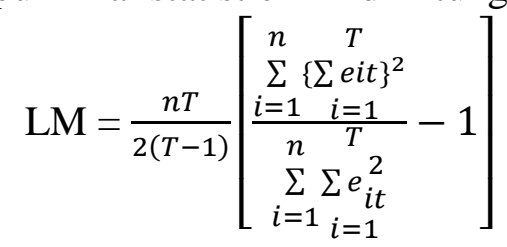

Dimana $\mathrm{n}$ adalah jumlah individu, $\mathrm{T}$ merupakan jumlah perode waktu dan eit adalah residual metode PLS. Uji LM ini didasarkan oleh distribusi Chi-square dengan derajat bebas sebesar 1. Jika hasil statistic LM lebih besar dari nilai kritis statistic chisquare, maka hipotesis nol akan ditolak, yang berarti estimasi yang tepat untuk regresi data panel adalah metode REM.

\section{Pemilihan antara model FEM dengan REM}

Untuk mengetahui apakah model Fixed effect lebih baik dari pada model Random Effect, digunakan uji Hausman. Dengan mengikuti criteria Wald, nilai Statistik Hausman ini akan mengikuti distribusi chi-square sebagai berikut :

$$
\mathrm{W}=x^{2}(K)=\left\{\widehat{\beta}, \widehat{\beta_{G l}}\right\} \sum-1\left\{\widehat{\beta}, \widehat{\beta_{G l}}\right\}
$$

Statistic uji Hausman ini mengikuti distribusi statistic chi-square dengan derajat bebas sebanyak jumlah peubah bebas (p). hipotesis nol ditolak jika nilai statistic Hausman lebih besar dari pada nilai statistic chi-square, hal ini berarti bahwa model yang tepat untuk regresi data panel adalah model FEM.

\section{HASIL DAN PEMBAHASAN \\ Perkembangan indeks pembangunan manusia Provinsi-Provinsi di Sumatera}

Indeks Pembangunan Manusia (IPM), menurut UNDP, adalah pengukuran perbandingan dari angka harapan hidup, melek huruf, pendidikan dan standar hidup untuk semua negara seluruh dunia. HDI (Human Development Index) digunakan untuk mengklasifikasikan apakah sebuah negara adalah negara maju, negara berkembang atau negara terbelakang dan juga untuk mengukur pengaruh dari kebijaksanaan ekonomi terhadap kualitas hidup.

Berdasarkan pada tabel 1 dibawah ini terlihat bahwa perkembangan indeks pembangunan manusia Provinsi-Provinsi di Sumatera tahun 2013-2017 mengalami peningkatan. Perkembangan indeks pembangunan manusia yang paling tertinggi yaitu 
pada Provinsi Kep Riau yaiu dengan rata-rata sebesar 73,72 persen atau daru 73,02 persen pada tahun 2013 meningkat menjadi sebesar 74,45 persen pada tahun 2017, hal ini terjadi dikarenkan Provinsi Kep Riau telah meningkatkan angka harapan sekolahmnya dan rata-rata sekolahnya serta angka harapan hidupnya meningkat. Sedangkan indeks pembangunan manusia yang paling terendah terjadi pada Provinsi Bengkulu yaitu dengan rata-rata sebesar 68,68 persen atau dari 67,50 pada tahun 2013 menjadi sebesar 69,95 persen pada tahun 2017, hal ini terjadi dikarenakan angka harapan hidupnya rendah dan angka pendidikannya rendah. Rata-rata indeks pembangunan manusia di Provinsi-provinsi Sumatera dari tahun 2013-2017 adalah sebesar 69,35 persen.

Tabel 1. Indeks pembangunan manusia Provinsi Provinsi di Sumatera tahun 2013-2017

\begin{tabular}{lccccccc}
\hline No & Provinsi & \multicolumn{6}{c}{ Indeks Pembangunan Manusia (\%) } \\
\cline { 3 - 7 } & & $\mathbf{2 0 1 3}$ & $\mathbf{2 0 1 4}$ & $\mathbf{2 0 1 5}$ & $\mathbf{2 0 1 6}$ & $\mathbf{2 0 1 7}$ & Rata-Rata \\
\hline 1 & Aceh & 67.30 & 67.81 & 69.45 & 70.00 & 70.60 & 69.03 \\
2 & Sumut & 68.36 & 68.87 & 69.51 & 70.00 & 70.57 & 69.46 \\
3 & Sumbar & 68.91 & 69.36 & 69.98 & 70.73 & 71.24 & 70.04 \\
4 & Riau & 69.91 & 70.33 & 70.84 & 71.20 & 71.79 & 70.81 \\
5 & Jambi & 67.76 & 68.24 & 68.89 & 69.92 & 69.99 & 68.96 \\
6 & Sumsel & 66.16 & 66.75 & 64.46 & 68.24 & 68.86 & 66.89 \\
7 & Bengkulu & 67.50 & 68.06 & 68.59 & 69.33 & 69.95 & 68.68 \\
8 & Lampung & 65.73 & 66.42 & 66.95 & 67.65 & 68.25 & 67.00 \\
9 & Babel & 67.92 & 68.27 & 69.05 & 69.55 & 69.99 & 68.95 \\
10 & Kep Riau & 73.02 & 73.40 & 73.75 & 73.99 & 74.45 & 73.72 \\
\hline \multicolumn{7}{c}{ Rata-rata } \\
\hline
\end{tabular}

Sumber: BPS, 2018 (diolah)

\section{Perkembangan pertumbuhan ekonomi Provinsi-Provinsi di Sumatera}

Menurut Arsyad (2002) teori pertumbuhan ekonomi menjelaskan mengenai factor-faktor yang menentukan pertumbuhan ekonomi dan prosesnya dalam jangka panjang, mengenai bagaimana factor-faktor itu berinteraksi satu dengan yang lainnya, sehingga menimbulkan terjadinya proses pertumbuhan.

Menurut Sukirno (2000) pertumbuhan ekonomi diartikan sebagai perkembangan kegiatan dalam perekonomian yang menyebabkan barang dan jasa yang diproduksi dalam masyarakat bertambah dan kemakmuran masyarakat meningkat. Jadi pertumbuhan ekonomi mengukur prestasi dari perkembangan suatu perekonomian dari suatu periode ke periode lainnya. Kemampuan suatu negara untuk menghasilkan barang dan jasa akan meningkat. Kemampuan yang meningkat ini disebabkan oleh pertambahan faktor-faktor produksi baik dalam jumlah dan kualitasnya. Investasi akan menambah barang modal dan teknologi yang digunakan juga makin berkembang. Di samping itu, tenaga kerja bertambah sebagai akibat perkembangan penduduk seiring dengan meningkatnya pendidikan dan keterampilan mereka.

Pertumbuhan ekonomi daerah lazimnya ditunjukan oleh indikator PDRB, walaupun mengandung beberapa kelemahan, namun sampai sekarang indikator ini masih tetap bisa diandalkan untuk mengetahui pertumbuhan ekonomi suatu daerah. Pertumbuhan ekonomi merupakan salah satu dasar yang digunakan oleh pemerintah dalam menentukan atau menyusun kebijakan ekonomi karena indikator ini menggambarkan pengukuran hasil-hasil pembangunan secara kuantitas.

Pertumbuhan ekonomi menunjukan sejauh mana aktivitas-aktivitas 
perekonomian akan menghasilkan tambahan bagi masyarakat dalam periode tertentu. Perekonomian dapat dikatakan meningkatnya pertumbuhannya bila pendapatan masyarakat lebih besar dari pendapatan pada tahun sebelumnya. Besarnya sumbangan produk domestik bruto juga menentukan besar tenaga kerja yang bekerja. Pertumbuhan ekonomi adalah merupakan perbandingan antara produk domestik bruto dan produk domestik bruto tahun sebelumnya. Untuk mengatahui gambaran pertumbuhan ekonomi Provinsi Provinsi di Sumatera kurun waktu 2013-2017 dapat dilihat dari tabel dibawah ini.

Tabel 2. Pertumbuhan ekonomi Provinsi-Provinsi di Sumatera tahun 2013-2017

\begin{tabular}{llllllcc}
\hline No & Provinsi & \multicolumn{5}{c}{ Pertumbuhan Ekonomi (\%) } \\
\cline { 3 - 7 } & & $\mathbf{2 0 1 3}$ & $\mathbf{2 0 1 4}$ & $\mathbf{2 0 1 5}$ & $\mathbf{2 0 1 6}$ & $\mathbf{2 0 1 7}$ & $\begin{array}{c}\text { Rata- } \\
\text { Rata (\%) }\end{array}$ \\
\hline 1 & Aceh & 2.61 & 1.55 & -0.73 & 3.30 & 4.19 & 2.18 \\
2 & Sumut & 6.07 & 5.23 & 5.10 & 5.18 & 5.12 & 5.34 \\
3 & Sumbar & 6.08 & 5.88 & 5.53 & 5.37 & 5.29 & 5.63 \\
4 & Riau & 2.48 & 2.71 & 0.22 & 2.23 & 2.71 & 2.07 \\
5 & Jambi & 6.84 & 7.36 & 4.21 & 4.27 & 4.64 & 5.46 \\
6 & Sumsel & 5.31 & 4.79 & 4.42 & 5.04 & 5.51 & 5.01 \\
7 & Bengkulu & 6.07 & 5.48 & 5.13 & 5.29 & 4.99 & 5.39 \\
8 & Lampung & 5.77 & 5.08 & 5.13 & 5.15 & 5.17 & 5.26 \\
9 & Babel & 5.20 & 4.67 & 4.08 & 4.11 & 4.51 & 4.51 \\
10 & Kep Riau & 7.21 & 6.60 & 6.02 & 5.02 & 2.01 & 5.37 \\
\hline \multicolumn{7}{c}{ Rata-rata } \\
\hline
\end{tabular}

Sumber: BPS, 2018 (diolah)

Perkembangan pertumbuhan ekonomi di Sumatera dapat dilihat pada tabel diatas. Rata-rata pertumbuhan ekonomi Provinsi di Sumatera selama tahun 2013-2017 yaitu sebesar 4,62 persen pertahun. pertumbuhan ekonomi tertinggi terjadi di Sumatera Barat dengan rata-rata sebesar 5,63 persen atau dari 6,08 persen pada tahun 2013 menjadi sebesar 5,29 persen pada tahun 2017, hal ini terjadi dikarenakan peningkatan kontyribusi sektor penyumbang PDRBnya terutama dari industri pengolahan dan pertanian. Pertumbuhan ekonomi terendah terjadi di Provinsi Riau dengan rata-rata pertumbuhannya dari tahun 2013-2017 sebesar 2,07 persen atau dari 2,48 persen pada tahun 2013 menjadi sebesar 2,71 pada tahun 2017, hal ini terjadi dikarenakan adanya penurunan kontribusi penyumbang PDRBnya.

\section{Perkembangan tingkat kemiskinan}

Kuncoro (2000) mendefinisikan kemiskinan sebagai ketidakmampuan untuk memenuhi standar hidup minimum. Di sisi lain Bank Dunia telah menunjukan adanya 3 dimensi. Bank Dunia sebagaimana dikutip Prayino dan Santoso (2001) menunjukkan adannya tiga dimensi kemiskinan, yaitu: Pertama, kemiskinan multidimensional artinya karena kebutuhan manusia itu bermacam-macam, maka kemiskinanpun memiliki banyak aspek. Dilihat dari kebijaksanaan umum, kemiskinan itu meliputi: aspek primer yang berupa miskin akan aset-aset, organisasi sosial politik, pengetahuan dan keterampilan. Aspek-aspek sekunder berupa miskin akan jaringan sosial, sumbersumber keuangan dan informasi. Dimensi-dimensi kemiskinan tersebut memanifestasikan dirinya dalam bentuk kekurangan gizi, air, dan perumahan yang tidak sehat serta perawatan kesehatan yang kurang baik. Kedua, aspek-aspek kemiskinan 
saling berkaitan baik secara langsun maupun tidak langsung. Hal ini berarti bahwa kemajuan atau kemunduran pada aspek lainnya. Ketiga, bahwa yang miskin adalah manusianya, baik secara individual maupun kolektif. Dimana kita sering mendengar perkataan kemiskinan perkotaan (urban proverty) dan kemisinan pedesaan (rural proverty).

Menurut Kuncoro (2003) terdapat tiga faktor penyebab kemiskinan jika dipandang dari sisi ekonomi. Pertama, kemiskinan muncul karena adanya ketidaksamaan pola kepemilikan sumber daya yang menimbulkan distribusi pendapatan yang timpang. Penduduk miskin hanya memiliki sumberdaya yang terbatas dan kualitasnya rendah. Kedua, kemiskinan muncul akibat perbedaan dalam kualitas sumber daya manusia. Kualitas sumber daya manusia yang rendah berarti produktifitasnya rendah, yang pada gilirannya upahnya rendah. Rendahnya kualitas sumber daya manusia ini karena rendahnya pendidikan, nasib yang kurang beruntung, adanya diskriminasi atau keturunan. Ketiga, kemiskinan muncul karena perbedaan akses dalam modal.

Tabel 3. Tingkat kemiskinan Provinsi-Provinsi di Sumatera tahun 2013-2017

\begin{tabular}{llcccccc}
\hline No & Provinsi & \multicolumn{7}{c}{ Kemiskinan (\%) } \\
\cline { 3 - 7 } & & $\mathbf{2 0 1 3}$ & $\mathbf{2 0 1 4}$ & $\mathbf{2 0 1 5}$ & $\mathbf{2 0 1 6}$ & $\mathbf{2 0 1 7}$ & $\begin{array}{c}\text { Rata- } \\
\text { Rata (\%) }\end{array}$ \\
\hline 1 & Aceh & 17.72 & 16.98 & 17.11 & 16.43 & 15.92 & 16.83 \\
2 & Sumut & 10.39 & 9.85 & 10.79 & 10.27 & 9.28 & 10.11 \\
3 & Sumbar & 7.56 & 6.89 & 6.71 & 7.14 & 6.75 & 7.01 \\
4 & Riau & 8.42 & 7.99 & 8.82 & 7.67 & 7.41 & 8.06 \\
5 & Jambi & 8.42 & 8.39 & 9.12 & 8.37 & 7.90 & 8.44 \\
6 & Sumsel & 14.06 & 13.62 & 13.77 & 13.39 & 13.10 & 13.58 \\
7 & Bengkulu & 17.75 & 17.09 & 17.16 & 17.03 & 15.56 & 16.91 \\
8 & Lampung & 14.39 & 14.21 & 13.53 & 13.86 & 13.04 & 13.80 \\
9 & Babel & 5.25 & 4.97 & 4.83 & 5.04 & 5.30 & 5.07 \\
10 & Kep Riau & 6.35 & 6.40 & 5.78 & 5.84 & 6.13 & 6.10 \\
\hline \multicolumn{7}{c}{ Rata-rata } \\
\hline
\end{tabular}

Sumber: BPS, 2018 (diolah)

Berdasarkan pada tabel diatas terlihat bahwa kemiskinan Provinsi Provinsi di Sumatera dari tahun 2013-2017 mengalami fluktuasi. Perkembangan kemiskinan yang paling tertinggi terjadi pada Provinsi Bengkulu yaitu sebesar 16,91 persen pertahunnya, hal ini dikarenakan tingkat pendidikan di Provinsi Bengkulu rendah. Diikuti dengan Provinsi Aceh dengan rata-rata sebesar 16,83 persen per tahunnya. Sedangkan perkembangan kemiskinan yang paling terendah terjadi pada Provinsi Bangka Belitung sebesar 5,07 persen. Setelah Provinsi Bangka Belitung diikuti oleh Provinsi Kep Riau dengan rata-rata sebesar 6,10 persen. Rata-rata perkembangan kemiskinan yang ada Provinsi Provinsi di Sumatera dari athun 2013 - 2017 adalah sebesar 10,59 persen pertahunnya.

Todaro (2003) mengungkapkan bahwa generalisasi yang paling tepat tentang kemiskinan adalah mereka yang ditempatkan di daerah pedesaan secara tidak seimbang, dan terutama sekali mereka yang bekerja di bidang pertanian atau kegiatan-kegiatan usaha bersama.

Konsep kemiskinan mengacu kepada garis kemiskinan disebut kemiskinan relatif, sedangkan konsep kemiskinan yang pengukurannya tidak didasarkan pada garis 
kemiskinan disebut kemiskinan absolut. Menurut tambunan (2004), kemiskinan relatif adalah suatu ukuran mengenai kesenjangan didalam kaitannya dengan tingkat rata-rata dan distribusi yang dimaksud. Sementara kemiskinan absolut adalah derajat kemiskinan di bawah, dimana kebutuhan minimum untuk bertahan hidup tidak terpenuhi. Ini adalah suatu ukuran tetap tidak berubah didalam bentuk suatu kebutuhan kalori minimum.

\section{Perkembangan tingkat pengangguran terbuka Provinsi-Provinsi di Sumatera}

Menurut Sukirno (2006) macam-macam pengangguran berdasarkan jam kerja dapat digolongkan antara lain pengangguran tersembunyi, pengangguran musiman, pengangguran setengan menganggur, dan pengangguran terbuka.

Tingkat pengangguran terbuka (TPT) adalah angka yang menunjukan banyaknya pengangguran terbuka terhadap 100 penduduk yang masuk dalam kategori angkatan kerja. Tingkat pengangguran terbuka sangat erat dengan hubungannya dengan laju pertumbuhan penduduk, dengan laju pertumbuhan yang tinggi akan meningkatkan jumlah angkatan kerja (penduduk usia kerja) yang kemudian besarnya angkatan kerja ini dapat menekan ketersediaan lapangan kerja di pasar kerja. Apabila mereka tidak bekerja konsekuensinya mereka tidak dapat memenuhi kebutuhan dengan baik.

Tabel 4. Tingkat pengangguran terbuka Provinsi-Provinsi di Sumatera tahun 2013-2017

\begin{tabular}{llllllll}
\hline \multirow{2}{*}{ No } & Provinsi & \multicolumn{5}{c}{ Tingkat Pengangguran Terbuka (\%) } & Rata-Rata \\
\cline { 3 - 6 } & & $\mathbf{2 0 1 3}$ & $\mathbf{2 0 1 4}$ & $\mathbf{2 0 1 5}$ & $\mathbf{2 0 1 6}$ & $\mathbf{2 0 1 7}$ & $(\%)$ \\
\hline 1 & Aceh & 10.12 & 9.02 & 9.93 & 7.57 & 6.57 & 8.64 \\
2 & Sumut & 6.45 & 6.22 & 6.71 & 5.84 & 5.60 & 6.16 \\
3 & Sumbar & 7.02 & 6.50 & 5.99 & 5.09 & 5.58 & 6.03 \\
4 & Riau & 5.48 & 6.56 & 7.83 & 7.43 & 6.22 & 6.70 \\
5 & Jambi & 4.76 & 5.08 & 4.34 & 4.00 & 3.87 & 4.41 \\
6 & Sumsel & 4.84 & 4.96 & 6.07 & 4.31 & 4.39 & 4.91 \\
7 & Bengkulu & 4.61 & 3.47 & 4.91 & 3.30 & 3.74 & 4.00 \\
8 & Lampung & 5.69 & 4.79 & 5.14 & 4.62 & 4.33 & 4.91 \\
9 & Babel & 3.65 & 5.14 & 6.29 & 2.60 & 3.78 & 4.29 \\
10 & Kep Riau & 5.63 & 6.69 & 6.20 & 7.69 & 7.16 & 6.67 \\
\hline
\end{tabular}

Sumber: BPS, 2018 (diolah)

Rata-rata $\quad \mathbf{5 . 6 7}$

Berdasarkan tabel diatas perkembangan pengangguran terbuka Provinsi di Sumatera tahun 2013-2017 mengalami perkembangan yang fluktuasi tiap Provinsi. Rata-rata perkembangan pengangguran terbuka Provinsi di Sumatera dari tahun 20132017 adalah sebesar 5,67 persen. Perkembangan pengangguran terbuka paling tertinggi terjadi di Aceh yaitu sebesar 8.64 persen, hal ini sebabkan karena banyaknya pengangguran terdidik yang terjadi di Provinsi Aceh dikarenakan banyaknya penduduk di Provinsi Aceh yang melanjutkan pendidikan lebih tinggi dan bisa mengurangi pengangguran. Sedangkan perkembangan pengangguran terbuka paling terendah terjadi di Provinsi Bengkulu yaitu sebesar 4.00 persen, hal ini disebabkan kualitas sumber daya manusia dan skill khususnya pada tenaga kerja yang ada serta meningkatkan tingkat pendidikannya agar bisa mendapatkan tenaga kerja yang bermutu dan bisa mengurangin pengangguran. 


\section{Perkembangan pengeluaran pemerintah}

Menurut sukirno (2006), pengeluaran publik yaitu pengeluaran yang bersifat menambah modal masyarakat dalam bentuk pembangunan, baik secara fisik maupun nonfisik. Pengeluaran pembangunan merupakan pengeluaran yang ditunjukkan untuk membiayai program-program pembangunan sehingga anggarannya selalu dapat disesuaikan dengan dana yang dimobilisasi.

Tabel 5. Perkembangan pengeluaran pemerintah Provinsi-Provinsi di Sumatera tahun 2013-2017

\begin{tabular}{|c|c|c|c|c|c|c|c|}
\hline \multirow[b]{2}{*}{ No } & \multirow[b]{2}{*}{ Provinsi } & \multicolumn{4}{|c|}{ Pengeluaran Pemerintah } & \multirow[b]{2}{*}{2017} & \multirow{2}{*}{$\begin{array}{c}\text { Rata- } \\
\text { Rata } \\
(\%)\end{array}$} \\
\hline & & 2013 & 2014 & 2015 & 2016 & & \\
\hline 1 & Aceh & - & 24.66 & 13.41 & 33.23 & 4.66 & 18.99 \\
\hline 2 & Sumut & - & 9.99 & 9.78 & 21.96 & 3.80 & 11.38 \\
\hline 3 & Sumbar & - & -2.63 & 12.56 & 14.81 & 3.91 & 7.16 \\
\hline 4 & Riau & - & 2.71 & 7.53 & 3.11 & 3.62 & 4.24 \\
\hline 5 & Jambi & - & 4.08 & 20.46 & 6.70 & 13.56 & 11.20 \\
\hline 6 & Sumsel & - & 5.43 & 0.31 & 10.19 & 1.70 & 4.41 \\
\hline 7 & Bengkulu & - & 10.78 & 14.57 & -0.00 & 32.75 & 14.52 \\
\hline 8 & Lampung & - & 10.18 & 12.06 & 18.52 & 5.95 & 11.68 \\
\hline 9 & Babel & - & -2.23 & 17.84 & 12.75 & 10.70 & 9.76 \\
\hline 10 & Kep Riau & - & 2.05 & 3.41 & 1.70 & 1.20 & 2.09 \\
\hline & \multicolumn{6}{|c|}{ Rata-rata } & 9.54 \\
\hline
\end{tabular}

Sumber: BPS, 2018 (diolah)

Berdasarkan pada tabel diatas terlihat perkembangan pengeluaran pemerintah tiap tahunnya Provinsi Provinsi di Sumatera dari tahun 2013-2017 mengalami peningkatan. Pengeluaran pemerintah yang paling tertinggi terjadi pada Provinsi di Aceh yaitu dengan ratarata sebesar 18,99 persen, hal ini terjadi dikarenakan propori pengeluaran belanja langsungnya meningkat terutama peningkatan belanaj pegawainya. Sedangkan pengeluaran pemerintah yang paling terendah terjadi pada Provinsi Kep.Riau yaitu dengan rata-rata sebesar 2,09 persen atau dari 2,5 persen pada tahun 2014 menurun menjadi 1,20 persen pada tahun 2017, hal ini dikarenakan proporsi belanja langsung dan tidak langsungnya menurun. Rata-rata pengeluaran pemerintah di Sumatera dari tahun 2013-2017 yaitu sebesar 9,54 persen.

\section{Pemilihan Model Regresi Data Panel}

Dari hasil ketiga model yang telah dianalisis selanjutnya akan ditentukan model yaitu Fem, REM dan PLS yang paling tepat untuk mengestimasi parameter regresi data panel.

\section{Pemilihan antara model PLS dengan FEM}

Untuk mengetahui apakah model FEM lebih baik dari pada model PLS dapat dilakukan dengan melihat signifikasi model FEM dapat dillakukan dengan uji statistiik F. Pengujian seperti ini dikenal juga dengan Uji Chow atau Likelihodd Test Ratio. Berikut ini adalah hasil yang didapat pada software Eviews 8.0 dibawah ini 
Table 6. Hasil pengujian pemilihan model PLS dengan FEM Redundant Fixed Effects Tests Pool: BARU

Test cross-section fixed effects

\begin{tabular}{lrrr}
\hline \hline Effects Test & Statistic & d.f. & Prob. \\
\hline \hline Cross-section F & 40.536506 & $(9,36)$ & 0.0000 \\
Cross-section Chi-square & 120.500742 & 9 & 0.0000 \\
\hline \hline
\end{tabular}

Sumber: Data diolah, 2019

Dari Tabel 6, menunjukan Pengujian menggunakan Chow-test/likelihood ratio test, yaitu:

Ho $=$ Model mengikuti pool

H1 = Model mengikuti Fixed

Interprestasi nilai $\mathrm{F}$ test maupun Chi-square signifikan ( $p$-value 0.0044 dan 0.00005 lebih besar dari $\alpha$ 0.05), sehingga Ho ditolak, maka Model FEM Lebih baik dari pada model PLS.

\section{Pemilihan antara model FEM dengan REM}

Untuk mengetahui apakah model Fixed Effect lebih baik dari model Random Effect, digunakan uji Hausman. Dengan mengikuti Kriteria Wald, nilai statistik Hausman ini akan mengikuti distribusi Chi-Square. Berikut ini hasil yang didapat pada software eviews 8.0 dibawah ini:

Tabel 7. Hasil pengujian pemilihan model FEM dengan REM

Correlated Random Effects - Hausman Test

Pool: BARU

Test cross-section random effects

\begin{tabular}{lccc}
\hline \hline Test Summary & Chi-Sq. Statistic & Chi-Sq. d.f. & Prob. \\
\hline \hline Cross-section random & $=18.445632$ & 4 & 0.0010 \\
\hline \hline
\end{tabular}

Sumber: Data diolah, 2019

Dari tabel 7, menunjukkan Pengujian menggunakan hausman test yaitu:

Ho = Random Effect (Individual Effect Uncorelated)

$\mathrm{H} 1=$ Fixed Effect

Interprestasi uji Hausman yaitu cross section Random dari eviews terlihat bahwa p-value $=0,0010<0.05$ sehingga. Ho diterima. Dengan demikian dapat disimpulkan bahwa model yang terbaik dalam pengujian ini adalah model FEM, lebih baik dari pada model PLS, REM.

\section{Estimasi dengan metode FEM (Fixed Effect)}

Berikut ini hasil dari model metode FEM (fixed effect) pertumbuhan ekonomi, kemiskinan, tingkat pengangguran terbuka dan pengeluaran pemerintah terhadap indeks pembangunan manusia Provinsi Provinsi di Sumatera. Menggunakan uji FEM dikarenakan untuk melihat perubahan antar waktu serta perubahan per Kabupaten antara 
variabel pertumbuhan ekonomi, tingkat kemiskinan, tingkat pengangguran terbuka dan pengeluaran pemerintah terhadap indeks pembangunan manusia

Tabel 8. Hasil pengujian regresi data panel metode FEM

Dependent Variable: IPM?

Method: Pooled Least Squares

Cross-sections included: 10

Total pool (balanced) observations: 50

\begin{tabular}{|c|c|c|c|c|}
\hline Variable & Coefficient & Std. Error & t-Statistic & Prob. \\
\hline $\mathrm{C}$ & 76.71200 & 3.100775 & 24.73962 & 0.0000 \\
\hline PE? & -0.306870 & 0.091047 & -3.370461 & 0.0018 \\
\hline TKM? & -0.633865 & 0.228255 & -2.776999 & 0.0087 \\
\hline TPT? & -0.281203 & 0.127904 & -2.198552 & 0.0344 \\
\hline PP? & 1.27E-07 & $3.60 \mathrm{E}-08$ & 3.516151 & 0.0012 \\
\hline \multicolumn{5}{|l|}{ Fixed Effects (Cross) } \\
\hline ACEH-C & 3.111997 & & & \\
\hline $\bar{S}$ SUMUT-C & -2.221735 & & & \\
\hline SUMBAR-C & -1.230005 & & & \\
\hline RIAU-C & -1.981520 & & & \\
\hline JAMBI-C & -1.007602 & & & \\
\hline SUMSEL_C & -1.387407 & & & \\
\hline BENGKULU-C & 4.484479 & & & \\
\hline LAMPUNG-C & -0.282437 & & & \\
\hline BABEL-C & -2.720813 & & & \\
\hline KEEPRIAU—C & 3.235042 & & & \\
\hline
\end{tabular}

Effects Specification

Cross-section fixed (dummy variables)

\begin{tabular}{lrlr}
\hline \hline R-squared & 0.943151 & Mean dependent var & 69.37700 \\
Adjusted R-squared & 0.922622 & S.D. dependent var & 2.088156 \\
S.E. of regression & 0.580861 & Akaike info criterion & 1.982885 \\
Sum squared resid & 12.14637 & Schwarz criterion & 2.518251 \\
Log likelihood & -35.57212 & Hannan-Quinn criter. & 2.186755 \\
F-statistic & 45.94262 & Durbin-Watson stat & 2.086089 \\
Prob(F-statistic) & 0.000000 & & \\
\hline \hline
\end{tabular}

Sumber: Data diolah, 2019

Dari Tabel 8, menunjukkan Interpretasi nilai slope untuk model FEM terlihat sama dengan model OLS biasa. Perbedaannya adalah terletak pada interpretasi nilai intersepnya, Individual effect.

Dari hasil regresi, maka dibuat persamaan regresi sebagai berikut:

$\mathrm{IPM}=$ 76,71200 $-0,306870 \mathrm{PE}-\mathbf{0 , 6 3 3 8 6 5} \mathrm{TKM}-\mathbf{0 , 2 8 1 2 0 3 \mathrm { TPT }}+\mathbf{0 , 0 0 0 0 0 0 0 1 2 7 P P}$

Dari hasil persamaan regresi variabel pertumbuhan ekonomi meningkat 1 persen maka indeks pembangunan manusia akan menurun sebesar 0,306870 persen. Variabel tingkat kemiskinan meningkat 1 persen maka indeks pembangunan manusia akan menurun sebesar 0,633865 persen. Variabel tingkat pengangguran terbuka meningkat 1 persen maka indeks pembangunan manusia akan menurun sebesar 0,633865 persen. Variabel Pengeluaran Pemerintah meningkat 1 juta maka indeks pembangunan manusia akan meningkat sebesar 0,127 persen. 


\section{Koefisien Determinasi $\left(\mathbf{R}^{2}\right)$}

Nilai R square $=0.943$ dapat diartikan besarnya Pertumbuhan Ekonomi (X1) Tingkat Kemiskinan (X2), Tingkat Pengangguran Terbuka (X3) dan Pengeluaran Pemerintah (X4) mampu mempengaruhi indeks pembangunan manusia sebesar 94,3 persen sedangkan 05,7 persen di pengaruhi atau dijelaskan oleh variabel lain yang tidak termasuk dalam penelitian ini.

\section{Uji F}

Pada $\alpha=5 \%$ dan di peroleh $\mathrm{df}=55(\mathrm{n}=55-4)$. Di dapat $\mathrm{F}_{\text {tabel }}$. Maka $\mathrm{F}_{\text {hitung }}=$ 45,492 > $\mathrm{F}$ tabel 2.786. artinya menolak Ho dan menerima $\mathrm{Ha}$, dengan demikian Pertumbuhan Ekonomi, Tingkat Kemiskinan, Tingkat Pengangguran Terbuka dan Pengeluaran Pemerintah berpengaruh terhadap Indeks Pembangunan manusia. Diperjelas kembali berdasarkan tabel 5.1.7 diatas diketahui juga bahwa nilai Prob (f Statistik) $0.000<0.05$. maka berarti Ho ditolak dan menerima Ha, yang artinya uji secara bersama sama menunjukkan bahwa Pertumbuhan Ekonomi, tingkat kemiskinan, tingkat pengangguran terbuka dan pengeluaran pemerintah berpengaruh signifikan terhadap indeks pembangunan manusia Provinsi Provinsi di Sumatera.

\section{Uji T}

Diketahui bahwa nilai t hitung variabel Pertumbuhan ekonomi yaitu $-3,370 \mathrm{t}$ hitung < t tabel 1,678 sehingga Ho ditolak dan diterima Ha. Jika dilihat dari Prob dari Pertumbuhan Ekonomi sebesar 0.0018 Prob < 0,05 maka Ho ditolak dan diterima Ha. Ini menunjukkan bahwa Pertumbuhan Ekonomi berpengaruh signifikan terhadap indeks pembangunan manusia Provinsi Provinsi di Sumatera

Variabel tingkat kemiskinan yaitu nilai $-2,776 \mathrm{t}$ hitung $<\mathrm{t}$ tabel 1,678 sehingga Ho ditolak dan diterima Ha. Jika dilihat dari Prob dari kemiskinan sebesar 0.0087 Prob $<0,05$ maka Ho ditolak dan diterima Ha. Ini menunjukkan bahwa tingkat kemiskinan berpengaruh signifikan terhadap indeks pembangunan manusia Provinsi Provinsi di Sumatera.

Variabel tingkat pengangguran terbuka yaitu 2,1985 t hitung $<\mathrm{t}$ tabel 1,678 sehingga Ho ditolak dan diterima Ha. Jika dilihat dari Prob dari Pertumbuhan Ekonomi sebesar 0.0344 Prob < 0,05 maka Ho ditolak dan diterima Ha. Ini menunjukkan bahwa tingkat pengangguran terbuka berpengaruh signifikan terhadap indeks pembangunan manusia Provinsi Provinsi di Sumatera

Variabel pengeluaran pemerintah yaitu 3,516 t hitung < t tabel 1,678 sehingga Ho ditolak dan diterima Ha. Jika dilihat dari Prob dari Pertumbuhan Ekonomi sebesar 0.0012 Prob < 0,05 maka Ho ditolak dan diterima Ha. Ini menunjukkan bahwa pengeluaran pemerintah berpengaruh signifikan terhadap indeks pembangunan manusia Provinsi Provinsi di Sumatera.

\section{KESIMPULAN DAN SARAN Kesimpulan}

Perkembangan indeks pembangunan manusia yang tertinggi terjadi di Provinsi Kep.Riau, sedangkan perkembangan yang terandah terjadi di Provinsi Sumatera Selatan. Perkembangan pertumbuhan ekonomi tertinggi terjadi di Sumatera Barat, sedangkan Pertumbuhan ekonomi terendah terjadi di Provinsi Riau. Perkembangan kemiskinan yang paling tertinggi terjadi pada Provinsi Bengkulu, sedangkan perkembangan kemiskinan yang terendah terjadi pada Provinsi Bangka Belitung. Perkembangan pengangguran terbuka paling tertinggi terjadi di Aceh, sedangkan perkembangan pengangguran terbuka paling terendah terjadi di Provinsi Bengkulu. Pengeluaran pemerintah yang paling tertinggi terjadi pada Provinsi di Sumatera Utara, sedangkan pengeluaran pemerintah yang paling terendah terjadi pada Provinsi Bangka Belitung. 
Pertumbuhan Ekonomi berpengaruh signifikan terhadap indeks pembangunan manusia. Tingkat Kemiskinan berpengaruh signifikan terhadap indeks pembangunan manusia. Tingkat pengangguran terbuka berpengaruh signifikan terhadap indeks pembangunan manusia. Pengeluaran pemerintah berpengaruh signifikan terhadap indeks pembangunan manusia.

\section{Saran}

Berdasarkan kesimpulan yang ada pemerintah harus lebih mengusahakan agar pertumbuhan ekonomi lebih meningkat dan masyarakat terbebas dari kemiskinan dan dapat hidup jauh lebih layak dan Indeks Pembangunan Manusia di Sumatera dapat terus meningkat.

Setelah melakukan pengujian secara individual dan bersama-sama terhadap variabel berpengaruh terhadap IPM di Sumatera maka hal yang harus dilakukan pemerintah yaitu memperhatikan masalah pertumbuhan ekonomi. Pertumbuhan ekonomi harus dikombinasikan dengan pemerataan. Begitu pula dengan masalah yang berhubungan dengan pengurangan kemiskinan dengan peningkatan produktivitas masyarakat melalui investasi di bidang pendidikan dan kesehatan agar IPM dapat lebih ditingkatkan.

\section{DAFTAR PUSTAKA}

Arsyad, Lincolin. (2002). Ekonomi Pembangunan. FE UGM: Yogyakarta.

Badan Pusat Statistik (BPS). (2001). Jambi Dalam Angka: Provinsi Jambi.

Dajan, Anto. (1986). Pengantar Metode Statistik Jilid I. LP3ES: Jakarta.

Dumairy. (2001). Perekonomian Indonesia. Erlangga: Jakarta.

Gujarati. Damodar. (2003). Economectric. Erlangga: Jakarta.

Kuncoro, Mudrajad. (2000). Ekonomi Pembangunan, Teori Masalah dan Kebijakan", Erlangga: Jakarta.

-------- (2003). Pengertian Kemiskinan. YKPN: Yogyakarta.

Napitupulu. (2007). Pengaruh Indikator Komposit Indeks Pembangunan Manusia Terhadap Penurunan Jumlah Penduduk Miskin di Sumatera Utara". Skripsi USU: Medan.

Paratdiredja, Ace. (2004). Ekonomika. UI Press: Jakarta.

Peraturan Menteri Dalam Negeri Nomor 13 Tahun 2006 Tentang Pengelolaan Keuangan Daerah.

Sukirno, Sadono. (2000). Pengantar Teori Ekonomi Makro. PT. Raja Grafindo Persada: Jakarta.

------- (2004). Teori Pengantar Makro Ekonomi. Edisi Ketiga. Jakarta. PT. Raja Grafindo Persada: Jakarta.

------ (2006), Pengantar Ekonomi Makro, LP FE-UI: Jakarta.

Simanjuntak, Payaman. (2000). Ekonomi Sumber Daya Manusia. PAU UI: Jakarta.

Tambunan, Tulus. (2004). Perekonomian Indonesia. Ghalia Indonesia: Jakarta.

Todaro. (2000). Pembangunan Ekonomi di Dunia Ketiga. Erlangga. Edisi Bahasa Indonesia. Buku II. Erlangga: Jakarta.

Todaro, Michael P. (2003). Pembangunan Ekonomi di Dunia Ketiga. Jakarta : Erlangga.

United Nation Development Programme (UNDP).(1996). The State of Human Development. UNDP: NewYork. 